\title{
Apolipoprotein A-I and Cancer
}

\author{
Maryam Zamanian-Daryoush * and Joseph A. DiDonato*
}

Department of Cellular and Molecular Medicine, and Center for Cardiovascular Diagnostics and Prevention, Cleveland Clinic, Cleveland, $\mathrm{OH}$, USA

High-density lipoprotein (HDL) and apolipoprotein A-I (apoA-l), the predominant protein in plasma HDL, have long been the focus of intense studies in the field of atherosclerosis and cardiovascular disease. ApoA-I, in large part, is responsible for HDL assembly and its main atheroprotective function, that of shuttling excess cholesterol from peripheral tissues to the liver for excretion (reverse cholesterol transport). Recently, a protective role for HDL in cancer was suggested from several large clinical studies where an inverse relationship between plasma HDL-cholesterol (HDL-C) levels and risk of developing cancer was noted. This notion has now been tested and found to be supported in mouse tumor studies, where increasing levels of apoA-I/HDL were discovered to protect against tumor development and provision of human apoA-I was therapeutic against established tumors. This mini-review discusses the emerging role of apoA-I in tumor biology and its potential as cancer therapeutic.

Edited by:

Norman Eric Miller,

University of Oxford, UK

Reviewed by:

Pramod C. Nair,

Flinders University of South Australia,

Australia

Md Abdul Hye Khan,

Medical College of Wisconsin, USA

*Correspondence:

Joseph A. DiDonato didonaj@ccf.org;

Maryam Zamanian-Daryoush zamanim@ccf.org

Specialty section:

This article was submitted to Experimental Pharmacology and Drug

Discovery,

a section of the journal

Frontiers in Pharmacology

Received: 20 July 2015 Accepted: 23 October 2015 Published: 12 November 2015

Citation:

Zamanian-Daryoush M and DiDonato JA (2015) Apolipoprotein A-I and Cancer.

Front. Pharmacol. 6:265. doi: 10.3389/fphar.2015.00265
Keywords: macrophage, apoA-I, HDL, cancer, cholesterol homeostasis, peptide mimetics, cancer therapeutic

\section{INTRODUCTION}

Apolipoprotein A-I (ApoA-I), the major protein component of high-density lipoprotein (HDL), is synthesized predominantly in the liver and the small intestine, and exists transiently in lipid-poor form. ApoA-I initiates assembly of HDL particles through interaction with ATP-binding cassette transporters at the surface of cells in the periphery extracting cholesterol and phospholipids. The HDL particle is further matured by lecithin cholesterol acyltransferase (LCAT) binding to apoA-I on HDL and converting cholesterol to cholesteryl ester (Sorci-Thomas et al., 2009). Cholesterol is transported within the constantly evolving 'HDL cargo' in circulation for excretion in liver through scavenger receptor class B, type 1 (SR-B1), a process known as reverse cholesterol transport (RCT; reviewed in Fisher et al. (2012), Rosenson et al. (2012), and Rader and Hovingh (2014)). Cholesterol accumulation and the ensuing inflammation that develops within the arterial wall are major instigators of atherosclerosis and cardiovascular disease (CVD; Hansson and Libby, 2006; Libby et al., 2009), and RCT is considered the primary atheroprotective function of HDL. A number of non-RCT atheroprotective functions of apoA-I/HDL have been described and include antiinflammatory (Cockerill et al., 1995; Bhattacharyya et al., 2008; Rye et al., 2009; de Souza et al., 2010; Fuhrman et al., 2010; Camont et al., 2011; Gordon et al., 2011), anti-apoptotic (de Souza et al., 2010; Fuhrman et al., 2010), and anti-oxidant activities (Bhattacharyya et al., 2008). Chronic inflammation, oxidative stress, lipids, and cholesterol, which promote atherosclerosis and CVD, have all been associated with tumorigenesis ( $\mathrm{Lu}$ et al., 2006; Freed-Pastor et al., 2012; Coussens et al., 2013; Noguti et al., 2013; Kobayashi et al., 2015). Given HDL’s beneficial role against these atherogenic processes, it was somewhat intuitive to suggest that HDL may also be protective against cancer. 


\section{ApoA-I/HDL IS ANTI-TUMORIGENIC}

\section{Clinical Observational Studies Suggest a Protective Role for ApoA-I in Cancer}

Analysis of Finnish male smokers in the Alpha-Tocopherol Beta-carotene (ATBC) lung cancer prevention study identified a significant inverse association between HDL-C levels and the risk for cancer of the lung, prostate, liver, and hematopoietic system (Ahn et al., 2009). This observation was further strengthened by a large meta-analysis of randomized controlled trials of lipidaltering therapies suggesting an inverse relationship between plasma HDL cholesterol levels and the incidence of cancer development during the conduct of the trials (Jafri et al., 2010). Specifically, for every $10 \mathrm{mg} / \mathrm{dL}$ increase in plasma HDL cholesterol level, a significant 36\% lower risk of cancer incidence was noted over 625,000 person-years of follow-up and >8,000 incidents of cancers cumulatively among the trials included in the meta-analysis (Jafri et al., 2010). Consistent with this finding, apoA-I has been identified as a biomarker with reduced plasma levels in patients with early stage ovarian cancer (OC) compared with normal individuals (Kozak et al., 2003, 2005; Zhang et al., 2004; Moore et al., 2006; Clarke et al., 2011; Kim et al., 2012). Furthermore, higher apoA1 mRNA levels in pre-chemotherapy effusions from patients diagnosed with advanced stage OC was observed to be an independent prognostic marker of longer overall survival (Tuft Stavnes et al., 2014). ApoA-I together with transthyretin and transferrin, both HDL-associated proteins, $\beta 2$ microglobulin, and prealbumin along with CA125 are currently being used in a US Food and drug administration approved plasma test for OC, and these combined biomarkers test is known as OVA $1{ }^{\circledR}$. This test is used to identify patients with early stage OC (Kozak et al., 2005; Su et al., 2007; Nossov et al., 2008; Nosov et al., 2009). A correlation with apoA-I levels and risk of disease has also been observed in other cancers. Serum apoA-I levels were found to be twofold lower in patients undergoing surgery for pancreatic cancer compared with healthy controls (Ehmann et al., 2007). Lower serum apoA-I levels were also associated with higher risk of breast cancer (BC; Chang et al., 2007) as well as BC recurrence (Lane et al., 1995), although other studies examining BC showed either no correlation with HDL-C (Furberg et al., 2004) or an inverse association observed only in pre-menopausal women, but not in post-menopausal women (Moorman et al., 1998; Kucharska-Newton et al., 2008). In contrast, a recent study reported a positive association between serum HDL-C and apoA-I levels with $\mathrm{BC}$ risk; however, this direct association was only seen in women who had not used hormone replacement therapy (HRT; Martin et al., 2015). In metastatic nasopharyngeal carcinoma (NPC), higher levels of serum apoA-I measured prior to chemotherapy correlated with better overall survival (Jiang et al., 2014). Additionally, in a large European prospective study, the European Prospective Investigation into Cancer and Nutrition (EPIC) study, an inverse association was found between HDL-C levels and endometrial cancer risk (Cust et al., 2007), and similarly plasma concentrations of HDL-C and apoA-I were found to be inversely associated with the risk of colon cancer (van Duijnhoven et al., 2011). Table 1 lists clinical studies which established an association between plasma levels of HDLC/apoA-I and risk of developing a broad spectrum of cancers.

\section{ApoA-I is Protective in Mouse Tumor Models}

Although the above-described clinical studies suggested, for the most part, lower apoA-I plasma levels correlate with poorer patient outcomes in a variety of cancers, they fall short of inferring causality. The first evidence supporting the notion that increasing levels of apoA-I may be protective against tumor development came from mouse tumor studies. Accordingly, there was an apoA-I gene dosage effect on Lewis lung tumor growth, with tumor size smallest for mice homozygous for the human apoA1 transgene $\left(\mathrm{h} A-I \mathrm{Tg}^{+/+}\right)$, intermediate tumor size in mice heterozygous for the human apoAl transgene (hA-I Tg $\mathrm{Tg}^{+/-}$, referred to hereon as simply apoA1 transgenic $(A-I T g)$ ), and largest tumor size in apoA1 null mice (A-I KO; ZamanianDaryoush et al., 2013). Furthermore, overall tumor burden and metastasis was strongly suppressed in response to challenge with the aggressive and metastatic syngeneic melanoma cells (B16F10L) in animals expressing the apoA1 transgene relative to apoA1 null or wild-type (WT) animals, culminating in improved overall survival (Zamanian-Daryoush et al., 2013). Similarly, in a mouse model of OC (ID8), ApoA-I transgene expression reduced tumor burden and led to a significant increase in survival ( $\mathrm{Su}$ et al., 2010).

\section{Infusion of Human ApoA-I Inhibits Tumor Development and is Therapeutic against Established Mouse Tumors}

Unequivocal support of an anti-neoplastic role for apoA-I came from animal studies where subcutaneous injections of human apoA-I prior to tumor inoculation prevented tumor development in A-I KO mice (Zamanian-Daryoush et al., 2013). More importantly, in a physiologically relevant setting, provision of apoA-I after tumor establishment not only prevented further development of the tumor but also led to tumor shrinkage (Zamanian-Daryoush et al., 2013). Although these protective effects were seen with the syngeneic mouse melanoma tumor, B16F10L, apoA-I therapy was also shown to be effective against human melanoma (A375) in nude mice (Zamanian-Daryoush et al., 2013). Based on these observations a potential role for apoA-I/HDL as an anti-cancer therapeutic has been proposed (Zamanian-Daryoush et al., 2013).

\section{ApoA-I/HDL MIMETIC PEPTIDES EXHIBIT ANTI-TUMOR ACTIVITY}

There has been considerable interest, in the HDL field, surrounding the therapeutic potential of a series of 18 amino acid peptides known as apoA-I/HDL mimetics, against cardiovascular disease. These short peptides have certain functional properties of the repeating amphipathic $\alpha$-helices of apoA-I without actually sharing any sequence homology (Getz and Reardon, 2014; Reddy et al., 2014). These peptides were originally screened 
TABLE 1 | Clinical studies investigating role of apoA-I/HDL in cancer.

\begin{tabular}{|c|c|c|c|}
\hline Cancer type & Clinical Study Objective & Conclusion & Reference \\
\hline Broad variety & $\begin{array}{l}\text { Analysis of } 24 \text { randomized controlled trials of lipid-altering therapy } \\
\text { ( } 145,743 \text { persons) to correlate baseline and on-treatment HDL-C levels } \\
\text { to risk of developing cancer ( } 2.7-5.2 \text { years follow up; } 625,477 \\
\text { person-years) }\end{array}$ & $\begin{array}{l}\text { For every } 10 \mathrm{mg} / \mathrm{dL} \text { increase in HDL-C, } 36 \% \text { lower } \\
\text { risk of developing cancer }\end{array}$ & $\begin{array}{l}\text { Jafri et al., } \\
2010\end{array}$ \\
\hline Ovarian & $\begin{array}{l}\text { ProteinChip biomarker System and Mass spectrometry-based } \\
\text { proteomic profiling (SELDI-TOF-MS) to identify disease associated } \\
\text { biomarkers in serum samples from patients with ovarian cancer (OC), } \\
\text { benign tumors, and healthy donors (109 OC, } 19 \text { benign tumors, and } 56 \\
\text { healthy controls) }\end{array}$ & $\begin{array}{l}\text { Three panels of proteins for: (i) early diagnosis of } \\
\text { neoplasia (benign or malignant) and (ii) } \\
\text { distinguishing benign from malignant }\end{array}$ & $\begin{array}{l}\text { Kozak et al., } \\
2003\end{array}$ \\
\hline $\begin{array}{l}\text { Ovarian/breast/ } \\
\text { colon/prostate }\end{array}$ & $\begin{array}{l}\text { ProteinChip biomarker System and Mass spectrometry- based } \\
\text { proteomic profiling (SELDI-TOF-MS) and immunoassays to identify and } \\
\text { validate biomarkers in serum samples from patients with early stage OC } \\
\text { as compared with healthy individuals and other cancers ( } 195 \mathrm{OC}, 166 \\
\text { benign tumors, } 142 \text { healthy controls for initial screening followed by } 41 \\
\text { OC, } 20 \text { each breast, colon, and prostate cancers with } 41 \text { healthy } \\
\text { controls for validation by immunoassays) }\end{array}$ & $\begin{array}{l}\text { Apolipoprotein A-I (ApoA-I; down-regulated in OC), } \\
\text { truncated transthyretin (TT; down-regulated in OC), } \\
\text { and a cleavage fragment of inter- } \alpha \text {-trypsin inhibitor } \\
\text { heavy chain H4 (up-regulated in OC) identified as } \\
\text { biomarkers for OC }\end{array}$ & $\begin{array}{l}\text { Zhang et al., } \\
2004\end{array}$ \\
\hline Ovarian & $\begin{array}{l}\text { Use of LC-MS/MS followed by immunoassays to identify } 5 \text { serum } \\
\text { protein biomarkers previously reported (Kozak et al., 2003). New } \\
\text { analysis of sera from } 43 \text { OC patients and } 31 \text { healthy controls }\end{array}$ & $\begin{array}{l}\text { ApoA-I (down-regulated), TT (down-regulated), } \\
\text { transferrin (down-regulated), and hemoglobin } \\
\text { (up-regulated) identified as biomarkers for OC }\end{array}$ & $\begin{array}{l}\text { Kozak et al., } \\
2005\end{array}$ \\
\hline Ovarian & $\begin{array}{l}\text { Independent evaluation of ApoA-I as biomarker for OC in } 182 \text { patient } \\
\text { ( } 42 \text { OC, } 65 \text { benign tumors, and } 76 \text { with digestive diseases) sera } \\
\text { collected at Mayo Clinic (1980-1989) }\end{array}$ & $\begin{array}{l}\text { ApoA-I and TT were confirmed as biomarkers for } \\
\mathrm{OC} \text { with their expression reduced in disease }\end{array}$ & $\begin{array}{l}\text { Moore et al., } \\
2006\end{array}$ \\
\hline Ovarian & $\begin{array}{l}\text { Pre-surgery blood samples ( } 41 \text { early stage (I/II), } 51 \text { late stage (III/IV), } 40 \\
\text { benign disease, and } 99 \text { healthy controls) analyzed by proteomics for } \\
\text { seven previously identified biomarkers }\end{array}$ & $\begin{array}{l}\text { ApoA-I as well as TT, and connective tissue } \\
\text { activating protein III (CTAPIII), were confirmed as a } \\
\text { panel of biomarker together with CA125 with } \\
\text { increased sensitivity for detection of early stage OC }\end{array}$ & $\begin{array}{l}\text { Clarke et al., } \\
2011\end{array}$ \\
\hline Ovarian & $\begin{array}{l}\text { Development of multiplexed bead-based immunoassay for detection of } \\
\text { known serum biomarkers of cancer ( } 118 \mathrm{OC}, 84 \text { benign ovarian } \\
\text { disease, } 61 \text { healthy controls) }\end{array}$ & $\begin{array}{l}\text { Combination of transthyretin, and apoA-I with } \\
\text { CA125 improved sensitivity and specificity of OC } \\
\text { diagnosis }\end{array}$ & Kim et al., 2012 \\
\hline Breast & $\begin{array}{l}\text { Lipid profile analysis in fasting patient sera prior to diagnostic biopsies } \\
(50 \text { malignant and } 50 \text { benign) }\end{array}$ & Lower apoA-I levels predict cancer recurrence & $\begin{array}{l}\text { Lane et al., } \\
1995\end{array}$ \\
\hline Breast & $\begin{array}{l}\text { Lipid profile analysis of pre-diagnostic sera from age-matched } 200 \text { (100 } \\
\text { before age } 50 \text { and } 100 \text { at age } 50 \text { or older) case-control BC patients } \\
\text { nested from an original cohort of 95,000 women to examine } \\
\text { prospective association of plasma HDL-C and BC incidence }\end{array}$ & $\begin{array}{l}\text { Low plasma HDL-C predicts risk of developing } \mathrm{BC} \\
\text { only in pre-menopausal women. Each } 1 \mathrm{mg} / \mathrm{dL} \\
\text { increase in } \mathrm{HDL}-\mathrm{C} \text { is associated with a } 4 \% \\
\text { reduction in risk of } \mathrm{BC}\end{array}$ & $\begin{array}{l}\text { Moorman et al., } \\
1998\end{array}$ \\
\hline Breast & $\begin{array}{l}\text { Assessed risk of BC associated with serum HDL-C in } 38,823 \\
\text { Norwegian women with a median follow-up of } 17.2 \text { years }\end{array}$ & $\begin{array}{l}\text { Low HDL-C, as part of the metabolic syndrome, is } \\
\text { associated with increased postmenopausal BC risk }\end{array}$ & $\begin{array}{l}\text { Furberg et al., } \\
2004\end{array}$ \\
\hline Breast & $\begin{array}{l}\text { Lipid profile analysis in fasting patient (Taiwanese) sera ( } 150 \text { cancer and } \\
71 \text { healthy controls) and association with BC risk }\end{array}$ & ApoA-I levels in serum inversely associated with $B C$ & $\begin{array}{l}\text { Chang et al., } \\
2007\end{array}$ \\
\hline Breast & $\begin{array}{l}\text { Evaluate association of baseline HDL-C levels with cancer incidence } \\
\text { using data from the Atherosclerosis Risk in Communities Study (ARIC) } \\
\text { cohort with follow-up from } 1987 \text { through } 2000\end{array}$ & $\begin{array}{l}\text { Modest direct association of low HDL-C with risk of } \\
\text { developing BC only in women who were } \\
\text { premenopausal at baseline }\end{array}$ & $\begin{array}{l}\text { Kucharska- } \\
\text { Newton et al., } \\
2008\end{array}$ \\
\hline Breast & $\begin{array}{l}\text { Multiple time point measurements of serum lipids and lipoproteins in a } \\
\text { nested case-control ( } 279 \text { cases and } 558 \text { matched control subjects) } \\
\text { study within a randomized long-term dietary intervention trial with 4,690 } \\
\text { women for an average of } 10 \text { years to assess the association of serum } \\
\text { lipids with the risk of cancer incidence based on menopausal status } \\
\text { and use of hormone replacement therapy (HRT) }\end{array}$ & $\begin{array}{l}\text { HDL-C and apoA-I were positively associated with } \\
\text { BC risk only when HRT was not used }\end{array}$ & $\begin{array}{l}\text { Martin et al., } \\
2015\end{array}$ \\
\hline
\end{tabular}


TABLE 1 | Continued

\begin{tabular}{|c|c|c|c|}
\hline Cancer type & Clinical Study Objective & Conclusion & Reference \\
\hline Nasopharyngeal & $\begin{array}{l}\text { Retrospective analysis of } 807 \text { patients with metastatic nasopharyngeal } \\
\text { carcinoma (NPC) to assess prognostic value of baseline serum lipids in } \\
\text { predicting overall survival }\end{array}$ & $\begin{array}{l}\text { Higher values of HDL-C and apoA-I were } \\
\text { associated with improved overall survival }\end{array}$ & $\begin{array}{l}\text { Jiang et al., } \\
2014\end{array}$ \\
\hline Endometrial & $\begin{array}{l}\text { Examined the association of pre-diagnostic plasma levels of lipids, } \\
\text { lipoproteins and other metabolic factors in developing cancer in a } \\
\text { nested case-control ( } 262 \text { cases and } 546 \text { matched control subjects) } \\
\text { study of the European Prospective Investigation into Cancer and } \\
\text { Nutrition (EPIC; 520,000 participants from } 10 \text { western European } \\
\text { countries) }\end{array}$ & $\begin{array}{l}\text { HDL-C levels were inversely correlated with the risk } \\
\text { of developing cancer }\end{array}$ & $\begin{array}{l}\text { Cust et al., } \\
2007\end{array}$ \\
\hline Colorectal & $\begin{array}{l}\text { Examined the association of pre-diagnostic plasma levels of lipids, } \\
\text { lipoproteins and other metabolic factors in developing cancer in a } \\
\text { nested case-control (1,238 cases, 1,238 matched control subjects) } \\
\text { study of the European Prospective Investigation into Cancer and } \\
\text { Nutrition (EPIC; } 520,000 \text { participants from } 10 \text { western European } \\
\text { countries) }\end{array}$ & $\begin{array}{l}\text { Higher pre-diagnostic HDL-C and apoA-I were } \\
\text { statistically significantly inversely associated with } \\
\text { risk of colon cancer, but not rectal cancer }\end{array}$ & $\begin{array}{l}\text { van Duijnhoven } \\
\text { et al., } 2011\end{array}$ \\
\hline
\end{tabular}

Clinical studies which established an association between plasma levels of apoA-I/HDL-C and risk of developing a broad spectrum of cancers.

for their ability to form class A amphipathic helices with lipid binding capability, a salient functional feature of apoA-I (Kanellis et al., 1980; Segrest et al., 1983; Anantharamaiah et al., 1985; Mendez et al., 1994). ApoA-I/HDL mimetics have been successfully used in a number of mouse models of atherosclerosis (Garber et al., 2001; Navab et al., 2010; Getz and Reardon, 2011) and shown to have anti-inflammatory and anti-oxidant activities as well as the ability to promote RCT (D'Souza et al., 2010; Ditiatkovski et al., 2013). These peptides have similar binding affinities for non-oxidized lipids but a significantly higher affinity for pro-inflammatory oxidized lipids (Van Lenten et al., 2008) and for lysophosphatidic acid (LPA; Su et al., 2010), relative to full-length apoA-I. LPA is known to promote tumor development (Mills and Moolenaar, 2003; Li et al., 2009) and has been identified as a biomarker for OC (Xu et al., 1998; Sutphen et al., 2004). Consequently, due to their anti-inflammatory activity and increased lipid binding properties apoA-I/HDL mimetics, when tested for anti-tumor activity, were shown to have protective activity in multiple mouse tumor models including ovarian (Su et al., 2010; Gao et al., 2011, 2012; Ganapathy et al., 2012), and colon cancer (Su et al., 2012). It was shown for OC that the primary functional activity of the mimetic peptides was due to squelching of the bioactive, tumor-promoting LPA and oxidized lipids that serve as potent tumor growth and angiogenic factors. The mimetic peptides $4 \mathrm{~F}$ and $5 \mathrm{~F}$ when injected or administered orally, inhibited tumor growth and reduced plasma levels of LPA in the tumor bearing mice (Su et al., 2010). Likewise, in another study the functional target of the apoA-I/HDL mimetic peptide L-4F was presumed to be LPA as administration of this HDL-mimetic peptide was shown to decrease circulating levels of LPA in mimetic-treated animals and demonstrated protection against colon cancer ( $\mathrm{Su}$ et al., 2012). ApoA-I mimetics were also reported to inhibit tumor angiogenesis in vivo and abrogate growth factor induced proliferation, migration, invasion, and tube formation of endothelial cells in vitro (Gao et al., 2011). The mimetics significantly decreased LPAinduced vascular endothelial growth factor (VEGF) production by cancer cells through inhibition of hypoxia-inducible factor- $1 \alpha$
(HIF-1 $\alpha)$ as well as interfering with VEGF-induced signaling in endothelial cells thus mitigating VEGF's ability to promote angiogenesis (Gao et al., 2011, 2012). Furthermore, the mimetics were shown to inhibit cell viability and proliferation of OC cells by reducing the oxidative stress in cancer cells through induced expression of the tumor suppressor enzyme, manganesecontaining superoxide dismutase (MnSOD; Ganapathy et al., 2012). Although these apoA-I/HDL peptide mimetics have demonstrated very interesting anti-tumor properties, their apparent mechanism of action (squelching LPA for the most part) does not appear to coincide with the anti-tumor mechanisms of actual apoA-I/HDL (Zamanian-Daryoush et al., 2013).

\section{MECHANISM OF ApoA-I/HDL ANTI-TUMOR ACTIVITY}

\section{ApoA-I/HDL Negatively Impacts Tumor-permissive Features of the Tumor Microenvironment}

Although the exact molecular mechanism of apoA-I/HDL anti-tumor activity is not known, studies with the syngeneic B16F10L tumors comparing those from apoA1 transgenic vs. A-I KO mice revealed that the overall net impact of host apoA-I on the tumor microenvironment is profound and manifold. These include but are not limited to the following as depicted in Figure 1: decreased recruitment of myeloid-derived suppressor cells (MDSC) and reduced angiogenesis resulting in decreased tumor volume; decreased matrix metalloproteinase9 (MMP9) protein levels and enzyme activity; decreased overall metastasis, increased accumulation of tumor-associated macrophages (TAMs) with an M1-like anti-tumor phenotype; increased levels of tumor cell killing macrophages; increased recruitment of CD8T cells and decreased levels of the antiapoptotic protein survivin within the tumor bed (ZamanianDaryoush et al., 2013). Unexpectedly, levels of the pro-angiogenic protein, VEGF-A, was higher in tumors from A-I Tg mice relative 


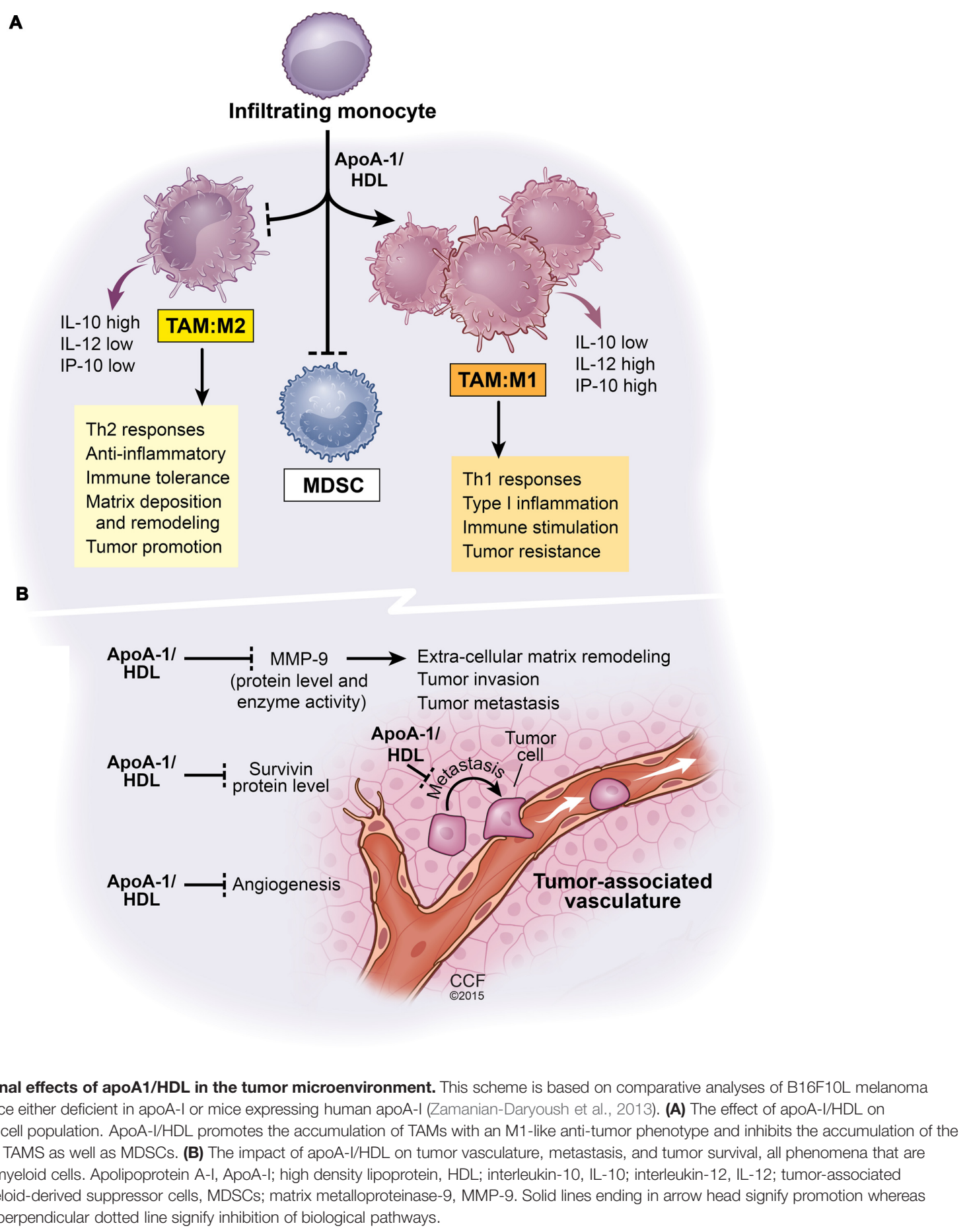

FIGURE 1 | Net functional effects of apoA1/HDL in the tumor microenvironment. This scheme is based on comparative analyses of B16F10L melanoma tumors resected from mice either deficient in apoA-I or mice expressing human apoA-I (Zamanian-Daryoush et al., 2013). (A) The effect of apoA-I/HDL on tumor-infiltrating myeloid cell population. ApoA-1/HDL promotes the accumulation of TAMs with an M1-like anti-tumor phenotype and inhibits the accumulation of the tumor promoting M2-like TAMS as well as MDSCs. (B) The impact of apoA-1/HDL on tumor vasculature, metastasis, and tumor survival, all phenomena that are subject to regulation by myeloid cells. Apolipoprotein A-I, ApoA-l; high density lipoprotein, HDL; interleukin-10, IL-10; interleukin-12, IL-12; tumor-associated macrophages, TAM; myeloid-derived suppressor cells, MDSCs; matrix metalloproteinase-9, MMP-9. Solid lines ending in arrow head signify promotion whereas solid lines ending with a perpendicular dotted line signify inhibition of biological pathways.

to A1KO mice (Zamanian-Daryoush et al., 2013). It may be that the VEGF-A protein quantified in these studies was VEGF$\mathrm{Ax}$, an anti-angiogenic VEGF-A variant recently reported to be a product of translational read-through (Eswarappa et al., 2014) though this remains to be proven. Both the antibody and the oligonucleotide probe sets used to detect VEGF-A in Zamanian-Daryoush et al. (2013) cannot distinguish between the two forms. Unlike the observations with apoA-I/HDL peptide mimetics, which appear to inhibit tumor growth by squelching/decreasing circulating levels of the bioactive tumor promoting lipid LPA; the plasma level of LPA, was found to be similar in B16F10L melanoma tumor-bearing $A-I$ KO vs. $A-I$ $\mathrm{Tg}$ animals (Zamanian-Daryoush et al., 2013), thus eliminating titration of this bioactive lipid as a functional mechanism, in this setting, for apoA-I protein (Zamanian-Daryoush et al., 2013). 


\section{ApoA-I/HDL Anti-tumor Activity Requires an Intact Innate and Adaptive Immune System for Full Anti-tumor Activity}

ApoA-I infusion studies with mice deficient in various aspects of immune system revealed that complete apoA-I anti-tumor activity requires both innate and adaptive arms of immunity. In particular, TAMs isolated from tumors resected from $A-I T g$ animals were skewed toward an M1-like phenotype and macrophages isolated from tumor-bearing $A-I T g$ animals exhibited enhanced cytotoxicity toward B16F10L tumor cells in vitro (Zamanian-Daryoush et al., 2013). Macrophages are innate immune cells with pivotal roles in tumor biology. Their ability to destroy tumors or promote their development is a function of their phenotypic plasticity, which is governed, in major part, by growth factors, cytokines, and bioactive lipids present in the tumor microenvironment (Mantovani et al., 2005; Martinez et al., 2009; Solinas et al., 2009; Liu and Yang, 2013). TAMs are in general, alternatively activated (M2like phenotype) and promote angiogenesis, tumor survival, and metastasis, whereas classically activated macrophages (M1like phenotype) inhibit these processes leading to tumor inhibition. Conversion of macrophage phenotype from M2 to M1 has been demonstrated to result in tumor inhibition in several murine tumor models (Colombo and Mantovani, 2005; Guiducci et al., 2005). The finding that in the tumor microenvironment, apoA-I/HDL promotes the accumulation of macrophages with pro-inflammatory, classically activated anti-tumor M1-like phenotype is in direct contrast with the traditional anti-inflammatory and immunosuppressive functions described for HDL in a typical inflammatory setting (Murphy et al., 2012). How apoA-I/HDL triggers this uncharacteristic effect is not known but is currently under investigation. The transcription factor activator of transcription factor 3 (ATF3) was recently identified as mediating anti-inflammatory and immune modulatory functions of HDL in macrophages (De Nardo et al., 2014). HDL induced the transcriptional expression of ATF3, which in turn inhibited the expression of some 130 toll-like receptor (TLR)-mediated pro-inflammatory genes with immune response-related functions (De Nardo et al., 2014). TLRs recognize pathogen-associated molecular pattern (PAMPs) molecules from viruses and microorganisms along with endogenously derived ligands such as damage-associated molecular pattern molecules (DAMPs) and can play important roles in both pro-and anti-tumor responses (Pradere et al., 2014). HDL inhibits lipopolysaccharide (LPS)-mediated TLR4 signaling by squelching the ligand itself and although HDL pretreatment was found to decrease cellular cholesterol concentration, it did not inhibit CpG-induced TLR9 signaling per se but reduced downstream gene expression by $\mathrm{CpG}$ through induction of ATF3 (De Nardo et al., 2014). These results indicate that apoA1/HDL can influence TLR signaling in normal inflammatory settings via at least two different routes.

HDL is an integral component of host immunity because its cargo, a series of bioactive proteins and lipids, has immunomodulatory activities. These activities include but are not limited to (i) ability to scavenge bacterial outer membrane components, LPS(Gram-negative bacteria) or lipoteichoic acid (LTA; Gram-positive bacteria) limiting their pro-inflammatory toxicity and protecting against sepsis (Levine et al., 1993; Birjmohun et al., 2007; Wendel et al., 2007; Guo et al., 2013), (ii) protection against intracellular bacteria such as mycobacteria (Cruz et al., 2008) and parasites (Vanhollebeke and Pays, 2010), (iii) in concert with ATP-binding cassette transporters ABCA1 and ABCG1, HDL has a role in control of hematopoietic stem and multipotential progenitor cell proliferation (YvanCharvet et al., 2010), and (iv) influencing immune cell response by modulating cholesterol content in membrane lipid rafts. Cholesterol accumulation in immune cells increases signaling by stabilizing lipid rafts in the plasma membrane as well as in other cellular membranes. Lipid rafts are cholesterol enriched micro-domains with sphingolipids and serve as docking sites for several receptors with important immunological functions, including TLRs (Fessler and Parks, 2011) and T- and B-cell receptors (TCRs; Gupta and DeFranco, 2007; Kabouridis and Jury, 2008). Cholesterol efflux by apoA-I/HDL via ABCA1 and ABCG1 disrupts lipid rafts and their associated signaling pathways (Triantafilou et al., 2002; Zhu et al., 2010). Thus cholesterol efflux-mediated modification of immune response was noted in: (i) monocytes/macrophages, inhibiting their activation and recruitment (Murphy et al., 2008) as well as skewing macrophages toward an M2-like anti-inflammatory immunosuppressive phenotype (Smythies et al., 2010; Feig et al., 2011; Murphy et al., 2012); (ii) neutrophils, inhibiting their migration and adhesion (Murphy et al., 2011); (iii) dendritic cells (DCs), inhibiting their maturation and their ability to induce T cell activation (Perrin-Cocon et al., 2012; Wang et al., 2012), while the immunoactive lipid sphingosine 1-phosphate (S1P) carried in HDL promotes an anti-inflammatory phenotype in DCs thus inhibiting a Th1 response (Idzko et al., 2002); (iv) T cells, inhibiting their activation and proliferation in peripheral lymph nodes in mice fed a high fat diet (Wilhelm et al., 2009). These observations are clearly supportive of apo A-I/HDL's role as a physiological modulator of membrane cholesterol and immune function in different pathophysiological conditions.

\section{Deletion of ApoA-I/HDL Receptors Lead to Altered Macrophage Phenotypes}

Recently, myeloid-specific or global deletion of Abcg1 in mice was reported to be anti-tumorigenic with macrophages displaying a clear shift from an M2-like to an M1-like phenotype (Sag et al., 2015). The anti-tumor effect was demonstrated to be driven by myeloid cells, and in large part due to the increased accumulation of cholesterol in macrophages. Studies on bone marrow-derived macrophages (BMDMs) from $A b c g 1^{-/}$mice compared to WT mice after treatment with either M1 or M2 polarizing cytokines and comparative analysis of M1 or M2 cell markers showed that the $A b c g 1^{-/-}$BMDMs were intrinsically biased to an M1 pro-inflammatory phenotype (Sag et al., 2015). These findings underscore the significance of cholesterol homeostasis in tumor immunity. Loss of Abcal in myeloid cells results in increased accumulation of free cholesterol and enhanced pro-inflammatory responses in macrophages, highlighting the 
normal anti-inflammatory function of these transporters (YvanCharvet et al., 2008; Zhu et al., 2008; Tang et al., 2009). Correspondingly, macrophages from mice globally deleted for scavenger receptor class $\mathrm{B}$, type $1(S r-b 1)$, have also been shown to exhibit hyperinflammatory responses (Cai et al., 2012). However, unlike the situation with $A b c a 1$ or $A b c g 1$ deletion, the heightened inflammatory responses are not due to alterations in cell membrane or total cell cholesterol levels (Cai et al., 2012). It is not known what effect loss of ABCA1 or SR-B1 protein expression either globally or myeloid-specifically has on tumorigenesis but by extrapolation from tumor studies in mice with ABCG1 loss, one might predict a protective effect due to the heightened pro-inflammatory phenotype these transporter-/receptor-deleted macrophages are known to exhibit. The emerging paradigm from the studies by Zamanian-Daryoush and that of Sag et al., is that TAMs can be converted from an M2-like to an M1like phenotype by either a hard-wiring to an M1 anti-tumor phenotype through loss of cholesterol/phospholipid transporter ABCG1 (Sag et al., 2015) and perhaps ABCA1 and SR-B1 or in response to increased apoA1/HDL levels; which by unknown mechanisms alters immune responses to factors within the tumor microenvironment and promotes the accumulation of TAMs with an M1-like phenotype at the expense of TAMs with an immune suppressive M2-like phenotype.

\section{CONCLUSION}

In cancer, lipid and cholesterol homeostasis is often dysregulated to facilitate the cancer cells' increased demand for these building blocks which are required for proliferation and evasion of apoptosis (Schaffner, 1981; Yoshioka et al., 2000; Kolanjiappan et al., 2003; Platz et al., 2009; Smith and Land, 2012). To this end, tumor cells can manipulate their intracellular cholesterol level by reducing expression of $\mathrm{ABCA} 1$ which effluxes cholesterol and increasing the expression of SR-B1 which influxes cholesterol. This phenomenon has been reported in several prostate, colon and BCs (Cao et al., 2004; Mooberry et al., 2010; Su et al., 2010; Smith and Land, 2012; Lee et al., 2013).

The ability to modulate lipid and cholesterol movement is at the core of apoA-I/HDL's actions resulting in profound physiological and cell phenotypic effects. Changes in cholesterol metabolism or levels of components of cholesterol homeostasis namely apoA-I/HDL, ABCA1, ABCG1, and SR-B1 are known

\section{REFERENCES}

Ahn, J., Lim, U., Weinstein, S. J., Schatzkin, A., Hayes, R. B., Virtamo, J., et al. (2009). Prediagnostic total and high-density lipoprotein cholesterol and risk of cancer. Cancer Epidemiol. Biomarkers. Prev. 18, 2814-2821. doi: 10.1158/10559965.EPI-08-1248

Anantharamaiah, G. M., Jones, J. L., Brouillette, C. G., Schmidt, C. F., Chung, B. H., Hughes, T. A., et al. (1985). Studies of synthetic peptide analogs of the amphipathic helix. Structure of complexes with dimyristoyl phosphatidylcholine. J. Biol. Chem. 260, $10248-10255$

Bhattacharyya, T., Nicholls, S. J., Topol, E. J., Zhang, R., Yang, X., Schmitt, D., et al. (2008). Relationship of paraoxonase 1 (PON1) gene polymorphisms and to affect immune responses which in turn impact anti-tumor effects. In fact, apoA-I/HDL's anti-tumor effects were observed maximally only in fully immune-competent animals (ZamanianDaryoush et al., 2013). Anti-tumor effects of apoA-I/HDL could be related to (i) the ability of apoA-I/HDL to modulate cholesterol content in immune or tumor cell membrane lipid rafts thus influencing signaling pathways, (ii) the lipid rafts' role as a platform for biologically active lipids and proteins that may impact the immune response, (iii) the cross-talk between the tumor and surrounding stromal cells. These possibilities are not mutually exclusive. ApoA-I/HDL peptide mimetics appear to primarily function through titrating out bioactive lipids and molecules which function as potent tumor cell angiogenic and growth factors. Although apoA-I/HDL may also perform similar titrating actions, the extent to which this activity is consequential in cancers other than in ovarian and perhaps colon cancer, is not as apparent. ApoA-I/HDL appears to function as an antitumor agent in large part by modulating the anti-tumor immune response. In the context of infection or atherogenesis, apoAI/HDL modulates macrophages toward an anti-inflammatory M2-like phenotype by effluxing cholesterol but in the tumor microenvironment, apoA-I/HDL promotes the accumulation of M1-like macrophages. At the present time, we do not know the mechanism involved in this process but this apparent dichotomy of apoA-I/HDL functional response in different inflammatory settings underscores the complexity of apoA-I/HDL biology and poses intellectual and experimental challenges toward a better understanding of this multifaceted plasma component.

\section{FUNDING}

Funding was provided by National Institutes of Health (NIH) grants P01HL076491 and P01HL098055.

\section{ACKNOWLEDGMENTS}

We thank J. Smith for careful review of the manuscript and S. L. Hazen for helpful scientific discussions and support. We are also grateful to Tom Hamilton for critical review of the Figure. "Illustration by David Schumick, BS, CMI. Reprinted with the permission of the Cleveland Clinic Center for Medical Art \& Photography () 2015. All Rights Reserved".

functional activity with systemic oxidative stress and cardiovascular risk. JAMA 299, 1265-1276. doi: 10.1001/jama.299.11.1265

Birjmohun, R. S., Van Leuven, S. I., Levels, J. H., Van 't Veer, C., Kuivenhoven, J. A., Meijers, J. C., et al. (2007). High-density lipoprotein attenuates inflammation and coagulation response on endotoxin challenge in humans. Arterioscler. Thromb. Vasc. Biol. 27, 1153-1158. doi: 10.1161/ATVBAHA.106.136325

Cai, L., Wang, Z., Meyer, J. M., Ji, A., and Van Der Westhuyzen, D. R. (2012). Macrophage SR-BI regulates LPS-induced pro-inflammatory signaling in mice and isolated macrophages. J. Lipid Res. 53, 1472-1481. doi: 10.1194/jlr.M 023234

Camont, L., Chapman, M. J., and Kontush, A. (2011). Biological activities of HDL subpopulations and their relevance to cardiovascular disease. Trends Mol. Med. 17, 594-603. doi: 10.1016/j.molmed.2011.05.013 
Cao, W. M., Murao, K., Imachi, H., Yu, X., Abe, H., Yamauchi, A., et al. (2004). A mutant high-density lipoprotein receptor inhibits proliferation of human breast cancer cells. Cancer Res. 64, 1515-1521. doi: 10.1158/0008-5472.CAN03-0675

Chang, S. J., Hou, M. F., Tsai, S. M., Wu, S. H., Hou, L. A., Ma, H., et al. (2007). The association between lipid profiles and breast cancer among Taiwanese women. Clin. Chem. Lab. Med. 45, 1219-1223. doi: 10.1515/CCLM.2007.263

Clarke, C. H., Yip, C., Badgwell, D., Fung, E. T., Coombes, K. R., Zhang, Z., et al. (2011). Proteomic biomarkers apolipoprotein A1, truncated transthyretin and connective tissue activating protein III enhance the sensitivity of CA125 for detecting early stage epithelial ovarian cancer. Gynecol. Oncol. 122, 548-553. doi: 10.1016/j.ygyno.2011.06.002

Cockerill, G. W., Rye, K. A., Gamble, J. R., Vadas, M. A., and Barter, P. J. (1995). High-density lipoproteins inhibit cytokine-induced expression of endothelial cell adhesion molecules. Arterioscler. Thromb. Vasc. Biol. 15, 1987-1994. doi: 10.1161/01.ATV.15.11.1987

Colombo, M. P., and Mantovani, A. (2005). Targeting myelomonocytic cells to revert inflammation-dependent cancer promotion. Cancer Res. 65, 9113-9116. doi: 10.1158/0008-5472.CAN-05-2714

Coussens, L. M., Zitvogel, L., and Palucka, A. K. (2013). Neutralizing tumorpromoting chronic inflammation: a magic bullet? Science 339, 286-291. doi: 10.1126/science.1232227

Cruz, D., Watson, A. D., Miller, C. S., Montoya, D., Ochoa, M. T., Sieling, P. A., et al. (2008). Host-derived oxidized phospholipids and HDL regulate innate immunity in human leprosy. J. Clin. Invest. 118, 2917-2928. doi: 10.1172/JCI34189

Cust, A. E., Kaaks, R., Friedenreich, C., Bonnet, F., Laville, M., Tjonneland, A., et al. (2007). Metabolic syndrome, plasma lipid, lipoprotein and glucose levels, and endometrial cancer risk in the European Prospective Investigation into Cancer and Nutrition (EPIC). Endocr. Relat. Cancer 14, 755-767. doi: 10.1677/ERC-070132

De Nardo, D., Labzin, L. I., Kono, H., Seki, R., Schmidt, S. V., Beyer, M., et al. (2014). High-density lipoprotein mediates anti-inflammatory reprogramming of macrophages via the transcriptional regulator ATF3. Nat. Immunol. 15, 152-160. doi: 10.1038/ni.2784

de Souza, J. A., Vindis, C., Negre-Salvayre, A., Rye, K. A., Couturier, M., Therond, P., et al. (2010). Small, dense HDL 3 particles attenuate apoptosis in endothelial cells: pivotal role of apolipoprotein A-I. J. Cell Mol. Med. 14, 608-620. doi: 10.1111/j.1582-4934.2009.00713.x

Ditiatkovski, M., D’souza, W., Kesani, R., Chin-Dusting, J., De Haan, J. B., Remaley, A., et al. (2013). An apolipoprotein A-I mimetic peptide designed with a reductionist approach stimulates reverse cholesterol transport and reduces atherosclerosis in mice. PLoS ONE 8:e68802. doi: 10.1371/journal.pone.0068802

D’Souza, W., Stonik, J. A., Murphy, A., Demosky, S. J., Sethi, A. A., Moore, X. L., et al. (2010). Structure/function relationships of apolipoprotein a-I mimetic peptides: implications for antiatherogenic activities of high-density lipoprotein. Circ. Res. 107, 217-227. doi: 10.1161/CIRCRESAHA.110.216507

Ehmann, M., Felix, K., Hartmann, D., Schnolzer, M., Nees, M., Vorderwulbecke, S., et al. (2007). Identification of potential markers for the detection of pancreatic cancer through comparative serum protein expression profiling. Pancreas 34, 205-214. doi: 10.1097/01.mpa.0000250128.57026.b2

Eswarappa, S. M., Potdar, A. A., Koch, W. J., Fan, Y., Vasu, K., Lindner, D., et al. (2014). Programmed translational readthrough generates antiangiogenic VEGF-Ax. Cell 157, 1605-1618. doi: 10.1016/j.cell.2014.04.033

Feig, J. E., Rong, J. X., Shamir, R., Sanson, M., Vengrenyuk, Y., Liu, J., et al. (2011). HDL promotes rapid atherosclerosis regression in mice and alters inflammatory properties of plaque monocyte-derived cells. Proc. Natl. Acad. Sci. U.S.A. 108, 7166-7171. doi: 10.1073/pnas.1016086108

Fessler, M. B., and Parks, J. S. (2011). Intracellular lipid flux and membrane microdomains as organizing principles in inflammatory cell signaling. J. Immunol. 187, 1529-1535. doi: 10.4049/jimmunol.1100253

Fisher, E. A., Feig, J. E., Hewing, B., Hazen, S. L., and Smith, J. D. (2012). High-density lipoprotein function, dysfunction, and reverse cholesterol transport. Arterioscler. Thromb. Vasc. Biol. 32, 2813-2820. doi: 10.1161/ATVBAHA.112.300133

Freed-Pastor, W. A., Mizuno, H., Zhao, X., Langerod, A., Moon, S. H., RodriguezBarrueco, R., et al. (2012). Mutant p53 disrupts mammary tissue architecture via the mevalonate pathway. Cell 148, 244-258. doi: 10.1016/j.cell.2011. 12.017
Fuhrman, B., Gantman, A., and Aviram, M. (2010). Paraoxonase 1 (PON1) deficiency in mice is associated with reduced expression of macrophage SR-BI and consequently the loss of HDL cytoprotection against apoptosis. Atherosclerosis 211, 61-68. doi: 10.1016/j.atherosclerosis.2010.01.025

Furberg, A. S., Veierod, M. B., Wilsgaard, T., Bernstein, L., and Thune, I. (2004). Serum high-density lipoprotein cholesterol, metabolic profile, and breast cancer risk. J. Natl. Cancer Inst. 96, 1152-1160. doi: 10.1093/jnci/djh216

Ganapathy, E., Su, F., Meriwether, D., Devarajan, A., Grijalva, V., Gao, F., et al. (2012). D-4F, an apoA-I mimetic peptide, inhibits proliferation and tumorigenicity of epithelial ovarian cancer cells by upregulating the antioxidant enzyme MnSOD. Int. J. Cancer 130, 1071-1081. doi: 10.1002/ijc.26079

Gao, F., Chattopadhyay, A., Navab, M., Grijalva, V., Su, F., Fogelman, A. M., et al. (2012). Apolipoprotein A-I mimetic peptides inhibit expression and activity of hypoxia-inducible factor-1alpha in human ovarian cancer cell lines and a mouse ovarian cancer model. J. Pharmacol. Exp. Ther. 342, 255-262. doi: 10.1124/jpet.112.191544

Gao, F., Vasquez, S. X., Su, F., Roberts, S., Shah, N., Grijalva, V., et al. (2011). L-5F, an apolipoprotein A-I mimetic, inhibits tumor angiogenesis by suppressing VEGF/basic FGF signaling pathways. Integr. Biol. (Camb) 3, 479-489. doi: $10.1039 / \mathrm{c} 0 \mathrm{ib} 00147 \mathrm{c}$

Garber, D. W., Datta, G., Chaddha, M., Palgunachari, M. N., Hama, S. Y., Navab, M., et al. (2001). A new synthetic class A amphipathic peptide analogue protects mice from diet-induced atherosclerosis. J. Lipid Res. 42, 545-552.

Getz, G. S., and Reardon, C. A. (2011). Apolipoprotein A-I and A-I mimetic peptides: a role in atherosclerosis. J. Inflamm. Res. 4, 83-92. doi: 10.2147/JIR.S12983

Getz, G. S., and Reardon, C. A. (2014). The structure/function of apoprotein A-I mimetic peptides: an update. Curr. Opin. Endocrinol. Diabetes Obes. 21, 129-133. doi: 10.1097/MED.0000000000000045

Gordon, S. M., Hofmann, S., Askew, D. S., and Davidson, W. S. (2011). High density lipoprotein: it's not just about lipid transport anymore. Trends Endocrinol. Metab. 22, 9-15. doi: 10.1016/j.tem.2010.10.001

Guiducci, C., Vicari, A. P., Sangaletti, S., Trinchieri, G., and Colombo, M. P. (2005). Redirecting in vivo elicited tumor infiltrating macrophages and dendritic cells towards tumor rejection. Cancer Res. 65, 3437-3446.

Guo, L., Ai, J., Zheng, Z., Howatt, D. A., Daugherty, A., Huang, B., et al. (2013). High density lipoprotein protects against polymicrobe-induced sepsis in mice. J. Biol. Chem. 288, 17947-17953. doi: 10.1074/jbc.M112.442699

Gupta, N., and DeFranco, A. L. (2007). Lipid rafts and B cell signaling. Semin. Cell Dev. Biol. 18, 616-626. doi: 10.1016/j.semcdb.2007.07.009

Hansson, G. K., and Libby, P. (2006). The immune response in atherosclerosis: a double-edged sword. Nat. Rev. Immunol. 6, 508-519. doi: 10.1038/nri1882

Idzko, M., Panther, E., Corinti, S., Morelli, A., Ferrari, D., Herouy, Y., et al. (2002). Sphingosine 1-phosphate induces chemotaxis of immature and modulates cytokine-release in mature human dendritic cells for emergence of Th2 immune responses. FASEB J. 16, 625-627.

Jafri, H., Alsheikh-Ali, A. A., and Karas, R. H. (2010). Baseline and on-treatment high-density lipoprotein cholesterol and the risk of cancer in randomized controlled trials of lipid-altering therapy. J. Am. Coll. Cardiol. 55, 2846-2854. doi: 10.1016/j.jacc.2009.12.069

Jiang, R., Yang, Z. H., Luo, D. H., Guo, L., Sun, R., Chen, Q. Y., et al. (2014). Elevated apolipoprotein A-I levels are associated with favorable prognosis in metastatic nasopharyngeal carcinoma. Med. Oncol. 31:80. doi: 10.1007/s12032-01 4-0080-y

Kabouridis, P. S., and Jury, E. C. (2008). Lipid rafts and T-lymphocyte function: implications for autoimmunity. FEBS Lett. 582, 3711-3718. doi: 10.1016/j.febslet.2008.10.006

Kanellis, P., Romans, A. Y., Johnson, B. J., Kercret, H., Chiovetti, R. Jr., Allen, T. M., et al. (1980). Studies of synthetic peptide analogs of the amphipathic helix. Effect of charged amino acid residue topography on lipid affinity. J. Biol. Chem. 255, 11464-11472.

Kim, Y. W., Bae, S. M., Lim, H., Kim, Y. J., and Ahn, W. S. (2012). Development of multiplexed bead-based immunoassays for the detection of early stage ovarian cancer using a combination of serum biomarkers. PLOS ONE 7:e44960. doi: 10.1371/journal.pone.0044960

Kobayashi, Y., Kashima, H., Wu, R. C., Jung, J. G., Kuan, J. C., Gu, J., et al. (2015). Mevalonate pathway antagonist inhibits proliferation of serous tubal intraepithelial carcinoma and ovarian carcinoma in mouse models. Clin. Cancer Res. 21, 4652-4662. doi: 10.1158/1078-0432.CCR-14-3368 
Kolanjiappan, K., Ramachandran, C. R., and Manoharan, S. (2003). Biochemical changes in tumor tissues of oral cancer patients. Clin. Biochem. 36, 61-65. doi: 10.1016/S0009-9120(02)00421-6

Kozak, K. R., Amneus, M. W., Pusey, S. M., Su, F., Luong, M. N., Luong, S. A., et al. (2003). Identification of biomarkers for ovarian cancer using strong anion-exchange ProteinChips: potential use in diagnosis and prognosis. Proc. Natl. Acad. Sci. U.S.A. 100, 12343-12348. doi: 10.1073/pnas.20336 02100

Kozak, K. R., Su, F., Whitelegge, J. P., Faull, K., Reddy, S., and FariasEisner, R. (2005). Characterization of serum biomarkers for detection of early stage ovarian cancer. Proteomics 5, 4589-4596. doi: 10.1002/pmic.2005 00093

Kucharska-Newton, A. M., Rosamond, W. D., Mink, P. J., Alberg, A. J., Shahar, E., and Folsom, A. R. (2008). HDL-cholesterol and incidence of breast cancer in the ARIC cohort study. Ann. Epidemiol. 18, 671-677. doi: 10.1016/j.annepidem.2008.06.006

Lane, D. M., Boatman, K. K., and Mcconathy, W. J. (1995). Serum lipids and apolipoproteins in women with breast masses. Breast Cancer Res. Treat. 34, 161-169. doi: 10.1007/BF00665788

Lee, B. H., Taylor, M. G., Robinet, P., Smith, J. D., Schweitzer, J., Sehayek, E., et al. (2013). Dysregulation of cholesterol homeostasis in human prostate cancer through loss of ABCA1. Cancer Res. 73, 1211-1218. doi: 10.1158/00085472.CAN-12-3128

Levine, D. M., Parker, T. S., Donnelly, T. M., Walsh, A., and Rubin, A. L. (1993). In vivo protection against endotoxin by plasma high density lipoprotein. Proc. Natl. Acad. Sci. U.S.A. 90, 12040-12044. doi: 10.1073/pnas.90.24.12040

Li, H., Wang, D., Zhang, H., Kirmani, K., Zhao, Z., Steinmetz, R., et al. (2009). Lysophosphatidic acid stimulates cell migration, invasion, and colony formation as well as tumorigenesis/metastasis of mouse ovarian cancer in immunocompetent mice. Mol. Cancer Ther. 8, 1692-1701. doi: 10.1158/15357163.MCT-08-1106

Libby, P., Ridker, P. M., Hansson, G. K., and On, A. (2009). Inflammation in atherosclerosis: from pathophysiology to practice. J. Am. Coll. Cardiol. 54, 2129-2138. doi: 10.1016/j.jacc.2009.09.009

Liu, G., and Yang, H. (2013). Modulation of macrophage activation and programming in immunity. J. Cell. Physiol. 228, 502-512. doi: $10.1002 /$ jcp. 24157

Lu, H., Ouyang, W., and Huang, C. (2006). Inflammation, a key event in cancer development. Mol. Cancer Res. 4, 221-233. doi: 10.1158/1541-7786.MCR-050261

Mantovani, A., Sica, A., and Locati, M. (2005). Macrophage polarization comes of age. Immunity 23, 344-346. doi: 10.1016/j.immuni.2005.10.001

Martin, L. J., Melnichouk, O., Huszti, E., Connelly, P. W., Greenberg, C. V., Minkin, S., et al. (2015). Serum lipids, lipoproteins, and risk of breast cancer: a nested case-control study using multiple time points. J. Natl. Cancer Inst. 107. doi: 10.1093/jnci/djv032

Martinez, F. O., Helming, L., and Gordon, S. (2009). Alternative activation of macrophages: an immunologic functional perspective. Annu. Rev. Immunol. 27, 451-483. doi: 10.1146/annurev.immunol.021908.132532

Mendez, A. J., Anantharamaiah, G. M., Segrest, J. P., and Oram, J. F. (1994). Synthetic amphipathic helical peptides that mimic apolipoprotein A-I in clearing cellular cholesterol. J. Clin. Invest. 94, 1698-1705. doi: 10.1172/JCI117515

Mills, G. B., and Moolenaar, W. H. (2003). The emerging role of lysophosphatidic acid in cancer. Nat. Rev. Cancer 3, 582-591. doi: 10.1038/nrc1143

Mooberry, L. K., Nair, M., Paranjape, S., Mcconathy, W. J., and Lacko, A. G. (2010). Receptor mediated uptake of paclitaxel from a synthetic high density lipoprotein nanocarrier. J. Drug Target. 18, 53-58. doi: 10.3109/10611860903156419

Moore, L. E., Fung, E. T., Mcguire, M., Rabkin, C. C., Molinaro, A., Wang, Z., et al. (2006). Evaluation of apolipoprotein A1 and posttranslationally modified forms of transthyretin as biomarkers for ovarian cancer detection in an independent study population. Cancer Epidemiol. Biomarkers Prev. 15, 1641-1646. doi: 10.1158/1055-9965.EPI-05-0980

Moorman, P. G., Hulka, B. S., Hiatt, R. A., Krieger, N., Newman, B., Vogelman, J. H., et al. (1998). Association between high-density lipoprotein cholesterol and breast cancer varies by menopausal status. Cancer Epidemiol. Biomarkers Prev. 7, 483-488.
Murphy, A. J., Westerterp, M., Yvan-Charvet, L., and Tall, A. R. (2012). Antiatherogenic mechanisms of high density lipoprotein: effects on myeloid cells. Biochim. Biophys. Acta 1821, 513-521. doi: 10.1016/j.bbalip.2011.08.003

Murphy, A. J., Woollard, K. J., Hoang, A., Mukhamedova, N., Stirzaker, R. A., Mccormick, S. P., et al. (2008). High-density lipoprotein reduces the human monocyte inflammatory response. Arterioscler. Thromb. Vasc. Biol. 28, $2071-$ 2077. doi: 10.1161/ATVBAHA.108.168690

Murphy, A. J., Woollard, K. J., Suhartoyo, A., Stirzaker, R. A., Shaw, J., Sviridov, D., et al. (2011). Neutrophil activation is attenuated by high-density lipoprotein and apolipoprotein A-I in in vitro and in vivo models of inflammation. Arterioscler. Thromb. Vasc. Biol. 31, 1333-1341. doi: 10.1161/ATVBAHA.111.226258

Navab, M., Shechter, I., Anantharamaiah, G. M., Reddy, S. T., Van Lenten, B. J., and Fogelman, A. M. (2010). Structure and function of HDL mimetics. Arterioscler. Thromb. Vasc. Biol. 30, 164-168. doi: 10.1161/ATVBAHA.109.187518

Noguti, J., Andersen, M. L., Cirelli, C., and Ribeiro, D. A. (2013). Oxidative stress, cancer, and sleep deprivation: is there a logical link in this association? Sleep Breath 17, 905-910. doi: 10.1007/s11325-012-0797-9

Nosov, V., Su, F., Amneus, M., Birrer, M., Robins, T., Kotlerman, J., et al. (2009). Validation of serum biomarkers for detection of early-stage ovarian cancer. Am. J. Obstet. Gynecol. 200:639e1-639e5. doi: 10.1016/j.ajog.2008.12.042

Nossov, V., Amneus, M., Su, F., Lang, J., Janco, J. M., Reddy, S. T., et al. (2008). The early detection of ovarian cancer: from traditional methods to proteomics. Can we really do better than serum CA-125? Am. J. Obstet. Gynecol. 199, 215-223. doi: 10.1016/j.ajog.2008.04.009

Perrin-Cocon, L., Diaz, O., Carreras, M., Dollet, S., Guironnet-Paquet, A. Andre, P., et al. (2012). High-density lipoprotein phospholipids interfere with dendritic cell Th1 functional maturation. Immunobiology 217, 91-99. doi: 10.1016/j.imbio.2011.07.030

Platz, E. A., Till, C., Goodman, P. J., Parnes, H. L., Figg, W. D., Albanes, D., et al. (2009). Men with low serum cholesterol have a lower risk of high-grade prostate cancer in the placebo arm of the prostate cancer prevention trial. Cancer Epidemiol. Biomarkers Prev. 18, 2807-2813. doi: 10.1158/1055-9965.EPI-090472

Pradere, J. P., Dapito, D. H., and Schwabe, R. F. (2014). The Yin and Yang of Tolllike receptors in cancer. Oncogene 33, 3485-3495. doi: 10.1038/onc.2013.302

Rader, D. J., and Hovingh, G. K. (2014). HDL and cardiovascular disease. Lancet 384, 618-625. doi: 10.1016/S0140-6736(14)61217-4

Reddy, S. T., Navab, M., Anantharamaiah, G. M., and Fogelman, A. M. (2014) Searching for a successful HDL-based treatment strategy. Biochim. Biophys. Acta 1841, 162-167. doi: 10.1016/j.bbalip.2013.10.012

Rosenson, R. S., Brewer, H. B. Jr., Davidson, W. S., Fayad, Z. A., Fuster, V., Goldstein, J., et al. (2012). Cholesterol efflux and atheroprotection: advancing the concept of reverse cholesterol transport. Circulation 125, 1905-1919. doi: 10.1161/CIRCULATIONAHA.111.066589

Rye, K. A., Bursill, C. A., Lambert, G., Tabet, F., and Barter, P. J. (2009). The metabolism and anti-atherogenic properties of HDL. J. Lipid Res. 50(Suppl.), S195-S200. doi: 10.1194/jlr.R800034-JLR200

Sag, D., Cekic, C., Wu, R., Linden, J., and Hedrick, C. C. (2015). The cholesterol transporter ABCG1 links cholesterol homeostasis and tumour immunity. Nat. Commun. 6:6354. doi: 10.1038/ncomms7354

Schaffner, C. P. (1981). Prostatic cholesterol metabolism: regulation and alteration. Prog. Clin. Biol. Res. 75A, 279-324.

Segrest, J. P., Chung, B. H., Brouillette, C. G., Kanellis, P., and Mcgahan, R. (1983). Studies of synthetic peptide analogs of the amphipathic helix. Competitive displacement of exchangeable apolipoproteins from native lipoproteins. J. Biol. Chem. 258, 2290-2295.

Smith, B., and Land, H. (2012). Anticancer activity of the cholesterol exporter ABCA1 gene. Cell Rep. 2, 580-590. doi: 10.1016/j.celrep.2012.08.011

Smythies, L. E., White, C. R., Maheshwari, A., Palgunachari, M. N., Anantharamaiah, G. M., Chaddha, M., et al. (2010). Apolipoprotein A-I mimetic $4 \mathrm{~F}$ alters the function of human monocyte-derived macrophages. Am. J. Physiol. Cell Physiol. 298, C1538-C1548. doi: 10.1152/ajpcell.00467.2009

Solinas, G., Germano, G., Mantovani, A., and Allavena, P. (2009). Tumorassociated macrophages (TAM) as major players of the cancer-related inflammation. J. Leukoc. Biol. 86, 1065-1073. doi: 10.1189/jlb.0609385

Sorci-Thomas, M. G., Bhat, S., and Thomas, M. J. (2009). Activation of lecithin:cholesterol acyltransferase by HDL ApoA-I central helices. Clin. Lipidol. 4, 113-124. doi: 10.2217/17584299.4.1.113 
Su, F., Grijalva, V., Navab, K., Ganapathy, E., Meriwether, D., Imaizumi, S., et al. (2012). HDL mimetics inhibit tumor development in both induced and spontaneous mouse models of colon cancer. Mol. Cancer Ther. 11, 1311-1319. doi: 10.1158/1535-7163.MCT-11-0905

Su, F., Kozak, K. R., Imaizumi, S., Gao, F., Amneus, M. W., Grijalva, V., et al. (2010). Apolipoprotein A-I (apoA-I) and apoA-I mimetic peptides inhibit tumor development in a mouse model of ovarian cancer. Proc. Natl. Acad. Sci. U.S.A. 107, 19997-20002. doi: 10.1073/pnas.1009010107

Su, F., Lang, J., Kumar, A., Ng, C., Hsieh, B., Suchard, M. A., et al. (2007). Validation of candidate serum ovarian cancer biomarkers for early detection. Biomark Insights 2, 369-375.

Sutphen, R., Xu, Y., Wilbanks, G. D., Fiorica, J., Grendys, E. C. Jr., LaPolla, J. P., et al. (2004). Lysophospholipids are potential biomarkers of ovarian cancer. Cancer Epidemiol. Biomarkers Prev. 13, 1185-1191.

Tang, C., Liu, Y., Kessler, P. S., Vaughan, A. M., and Oram, J. F. (2009). The macrophage cholesterol exporter ABCA1 functions as an anti-inflammatory receptor. J. Biol. Chem. 284, 32336-32343. doi: 10.1074/jbc.M109.047472

Triantafilou, M., Miyake, K., Golenbock, D. T., and Triantafilou, K. (2002). Mediators of innate immune recognition of bacteria concentrate in lipid rafts and facilitate lipopolysaccharide-induced cell activation. J. Cell Sci. 115, 26032611.

Tuft Stavnes, H., Nymoen, D. A., Hetland Falkenthal, T. E., Kaern, J., Trope, C. G., and Davidson, B. (2014). APOA1 mRNA expression in ovarian serous carcinoma effusions is a marker of longer survival. Am. J. Clin. Pathol. 142, 51-57. doi: 10.1309/AJCPD8NBSHXRXQL7

van Duijnhoven, F. J., Bueno-De-Mesquita, H. B., Calligaro, M., Jenab, M., Pischon, T., Jansen, E. H., et al. (2011). Blood lipid and lipoprotein concentrations and colorectal cancer risk in the European Prospective Investigation into Cancer and Nutrition. Gut 60, 1094-1102. doi: 10.1136/gut.2010.225011

Vanhollebeke, B., and Pays, E. (2010). The trypanolytic factor of human serum: many ways to enter the parasite, a single way to kill. Mol. Microbiol. 76, 806-814. doi: 10.1111/j.1365-2958.2010.07156.x

Van Lenten, B. J., Wagner, A. C., Jung, C. L., Ruchala, P., Waring, A. J., Lehrer, R. I., et al. (2008). Anti-inflammatory apoA-I-mimetic peptides bind oxidized lipids with much higher affinity than human apoA-I. J. Lipid Res. 49, 2302-2311. doi: 10.1194/jlr.M800075-JLR200

Wang, S. H., Yuan, S. G., Peng, D. Q., and Zhao, S. P. (2012). HDL and ApoA-I inhibit antigen presentation-mediated $\mathrm{T}$ cell activation by disrupting lipid rafts in antigen presenting cells. Atherosclerosis 225, 105-114. doi: 10.1016/j.atherosclerosis.2012.07.029

Wendel, M., Paul, R., and Heller, A. R. (2007). Lipoproteins in inflammation and sepsis. II. Clin. Aspects. Intensive Care Med. 33, 25-35. doi: 10.1007/s00134-0060433-x

Wilhelm, A. J., Zabalawi, M., Grayson, J. M., Weant, A. E., Major, A. S., Owen, J., et al. (2009). Apolipoprotein A-I and its role in lymphocyte cholesterol homeostasis and autoimmunity. Arterioscler. Thromb. Vasc. Biol. 29, 843-849. doi: 10.1161/ATVBAHA.108.183442

Xu, Y., Shen, Z., Wiper, D. W., Wu, M., Morton, R. E., Elson, P., et al. (1998). Lysophosphatidic acid as a potential biomarker for ovarian and other gynecologic cancers. JAMA 280, 719-723. doi: 10.1001/jama.280.8.719

Yoshioka, Y., Sasaki, J., Yamamoto, M., Saitoh, K., Nakaya, S., and Kubokawa, M. (2000). Quantitation by (1)H-NMR of dolichol, cholesterol and cholinecontaining lipids in extracts of normal and phathological thyroid tissue. NMR Biomed. 13, 377-383. doi: 10.1002/1099-1492(200011)13:7<377::AIDNBM658> 3.0.CO;2-E

Yvan-Charvet, L., Pagler, T., Gautier, E. L., Avagyan, S., Siry, R. L., Han, S., et al. (2010). ATP-binding cassette transporters and HDL suppress hematopoietic stem cell proliferation. Science 328, 1689-1693. doi: 10.1126/science.11 89731

Yvan-Charvet, L., Welch, C., Pagler, T. A., Ranalletta, M., Lamkanfi, M., Han, S., et al. (2008). Increased inflammatory gene expression in ABC transporterdeficient macrophage $s$ : free cholesterol accumulation, increased signaling via toll-like receptors, and neutrophil infiltration of atherosclerotic lesions. Circulation 118, 1837-1847. doi: 10.1161/CIRCULATIONAHA.108.793869

Zamanian-Daryoush, M., Lindner, D., Tallant, T. C., Wang, Z., Buffa, J., Klipfell, E., et al. (2013). The cardioprotective protein apolipoprotein A1 promotes potent anti-tumorigenic effects. J. Biol. Chem. 288, 21237-21252. doi: 10.1074/jbc.M113.468967

Zhang, Z., Bast, R. C. Jr., Yu, Y., Li, J., Sokoll, L. J., Rai, A. J., et al. (2004). Three biomarkers identified from serum proteomic analysis for the detection of early stage ovarian cancer. Cancer Res. 64, 5882-5890. doi: 10.1158/0008-5472.CAN04-0746

Zhu, X., Lee, J. Y., Timmins, J. M., Brown, J. M., Boudyguina, E., Mulya, A., et al. (2008). Increased cellular free cholesterol in macrophage-specific Abcal knockout mice enhances pro-inflammatory response of macrophages. J. Biol. Chem. 283, 22930-22941. doi: 10.1074/jbc.M801408200

Zhu, X., Owen, J. S., Wilson, M. D., Li, H., Griffiths, G. L., Thomas, M. J., et al. (2010). Macrophage ABCA1 reduces MyD88-dependent Toll-like receptor trafficking to lipid rafts by reduction of lipid raft cholesterol. J. Lipid. Res. 51, 3196-3206. doi: 10.1194/jlr.M006486

Conflict of Interest Statement: Drs. Maryam Zamanian-Daryoush and Joseph A. DiDonato report being listed as co-inventor on pending and issued patents held by the Cleveland Clinic.

Copyright (C) 2015 Zamanian-Daryoush and DiDonato. This is an open-access article distributed under the terms of the Creative Commons Attribution License (CC BY). The use, distribution or reproduction in other forums is permitted, provided the original author(s) or licensor are credited and that the original publication in this journal is cited, in accordance with accepted academic practice. No use, distribution or reproduction is permitted which does not comply with these terms. 